\title{
The Impact of Peer Instruction on Ninth Grade Students' Trigonometry Knowledge
}

\section{O impacto da instrução de pares no conhecimento de trigonometria em alunos da nona série}

ORCID id 0000-0002-6364-5346

Kaymak Serkan ${ }^{* *}$

ORCID id 0000-0002-9730-0987

Almas Abdullah ${ }^{* * *}$

ORCID id 0000-0002-6702-0335

Nurbavliyev Omarbek ${ }^{* * * *}$

ORCID id 0000-0002-8992-4589

\begin{abstract}
In this study, we conducted peer instruction (PI) activities to promote student participation in the learning process and test the hypothesis that PI improves student achievement. Two ninth-grade classes were randomly assigned as treatment and control groups. Pre-test and post-test data were obtained for measuring mathematics achievement in trigonometry. Data were analyzed using analysis of covariance procedures with an alpha significance level of 0.05 . Results indicated no significant effects of peer instruction on achievement. This study implies that more robust studies are needed to reveal the real effect of PI.
\end{abstract}

Keywords: Mathematics achievement. Peer instruction. Teaching trigonometry.

\section{Resumo}

Neste estudo, atividades de instrução entre pares (IP) foram realizadas para promover a participação dos alunos no processo de aprendizagem e testar a hipótese de que IP melhora o desempenho dos alunos. Duas classes da nona série foram designadas, aleatoriamente, para grupo experimental e grupo de controle. Dados pré-teste e pós-teste foram obtidos para a medida de desempenho na matemática, em trigonometria. Os dados foram analisados por meio de procedimentos de análise de covariância, com nível de significância alfa de 0,05 . Os resultados não

\footnotetext{
* Doctor in Physics Education, Middle East Technical University (METU). Professor at Department of Sience Education, Suleyman Demirel University (SDU), Almaty, Kaskelen, Kazakhstan. E-mail: baltanuri@gmail.com. ** Master in Mathematics Education, Suleyman Demirel University (SDU). Senior Lecturer at Department of Sience Education, Suleyman Demirel University (SDU), Almaty, Kaskelen, Kazakhstan. Email: serkan.kaymak@sdu.edu.kz.

*** Master in Mathematic Education, Suleyman Demirel University (SDU). Senior Lecturer at Department of Sience Education, Suleyman Demirel University (SDU), Almaty, Kaskelen, Kazakhstan. Email: abdullah.almas@sdu.edu.kz

**** Master in Mathematic Education, Suleyman Demirel University (SDU). Senior Lecturer at Department of Sience Education, Suleyman Demirel University (SDU), Almaty, Kaskelen, Kazakhstan. Email: omarbek.nurbavliyev@sdu.edu.kz.
} 
indicaram efeitos significativos da instrução de pares no desempenho. Esta pesquisa indica que estudos mais consistentes são necessários para revelar o real efeito do IP.

Palavras-chave: Desempenho em matemática. Instrução de pares. Ensino de trigonometria.

\section{Introduction}

Peer instruction (PI) that has been extensively adopted in science classes is a form of active learning, and the overall procedure is a version of the think-pair-share technique (PRAHL, 2017). It is usually defined as a chance for classmates to discuss concepts or to share answers to questions in the classroom atmosphere, where they have further occasions for additional communication with their teachers (KNIGHT; BRAME, 2018). The overall aim of this study is to compare the effects of PI enhanced with the concept test to regular instruction on $9^{\text {th }}$-grade students' achievements in trigonometry.

Therefore, we tested the hypothesis that peer instruction enhances meaningful learning or transfer, defined as the student's ability to solve novel problems or the ability to extend what has been learned in one context to new contexts.

In a typical PI sequence, the instructor poses a conceptual question and allows students the opportunity to think individually and record their answers independently, often by voting using clickers or online response systems (BALTA; PERERA-RODRÍGUEZ; HERVÁSGÓMEZ, 2018). The answers are shown as a response graph (usually a histogram) on a screen in front of the class. They can see from the response graph that others also have different considerations.

Then, before they submit a new response, students form small groups to discuss their responses with their peers, to clarify their reasoning, and convince each other. After a few minutes, students can answer the question again and perhaps make a different choice. A new response graph is then displayed, which now includes the correct answer and leads to a classroom-wide discussion (with the teacher involved). The discussion with students aims to reason on the correct answer. When the discussion is over, and everyone agrees, a new cycle begins. The whole procedure, from start to finish, takes about five to eight minutes. This is the core of PI, which can improve teaching and promote learning through discussion with peers (CROUCH; MAZUR, 2001).

PI includes many features that support learning, such as cooperative learning, interactive engagement (FAGEN; CROUCH; MAZUR, 2002), critical thinking, problem-solving, and decision-making skills (RAO; DICARLO, 2000). The success of PI comes from the fact that 
individual success is enhanced by the success of peers (JOHNSON; JOHNSON, 2009). It enables students to describe their reasoning and engage in discussions with their peers. PI allows students to become engaged participants (LUCAS, 2009).

According to the review of peer instruction by Vickrey et al. (2015), PI (a) can increase students' conceptual understanding, (b) improve their problem-solving skills, (c) is effective in multiple disciplines, and (d) is effective in courses at different levels. In their meta-analysis, Balta et al. (2017) showed that PI has a positive effect on learning, and it has been used in a wide range of courses and countries to create interactivity during lectures.

PI has been shown frequently from research to increase students' conceptual reasoning and quantitative problem-solving skills (CROUCH; MAZUR, 2001; FAGEN; CROUCH; MAZUR, 2002; LASRY; MAZUR; WATKINS, 2008). PI increases student achievement and attitudes toward science (JOHNSON; JOHNSON, 2009). It offers opportunities for formative assessment with instant feedback and thus includes opportunities for students to monitor their understanding (MCDONNELL; MULLALLY, 2016). "Studies have measured the impact of PI on learning gains, problem-solving skills, and student retention" (VICKREY et al., 2015, p. 2). PI activities stimulate student participation in the learning procedure (GIULIODORI; LUJAN; DICARLO, 2006). PI allows students to test their knowledge and relate it to new circumstances in a safe, helpful setting. This type of learning practice lets students assess their concepts and practices while providing feedback about their development (GIULIODORI; LUJAN; DICARLO, 2006).

Even though initial studies on PI were done in physics (MAZUR, 1997), studies on PI can be seen in many disciplines such as physiology (GIULIODORI; LUJAN; DICARLO, 2006), economics (GHOSH; RENNA, 2006), mathematics (LUCAS, 2009) and recently, in geology (MORA, 2010) where the researchers found PI to enhance student performance on qualitative questions, understand new concepts, and collaboratively reflect on course content. Student attitudes towards peer instruction are commonly positive; students report that the method helps them learn course material and that the instant feedback it provides is valuable (KNIGHT; BRAME, 2018). A common problem with PI is that one or two students may control the argument, making the rest of the group inactive members. Further, when PI is implemented, the lecture time is reduced, so students may have to spend extra time reading their textbooks to understand course material (LUCAS, 2009). Another significant problem in the implementation of PI was whether displaying the class responses to a question biases their subsequent answer. The findings of Perez et al. (2010) suggested that seeing the most common answer can bias a student's second choice on a question. 


\subsection{Peer Instruction in Math Classes}

Although the initial implementation of PI in classrooms was done in 1991 (MAZUR, 1997) in physics, it took a long time to apply it in Math (CHAPMEN, 2004). Our literature review revealed 23 studies related to PI in mathematics topics. The effect of PI on various math topics such as rational numbers (YAVUZ, 2014), whole numbers, integers, decimals and fractions (VASAY, 2010), area of polygons, and the volume of cylinders, spheres, and cones (BLOYD, 2015) has been investigated. Extensive research has been done on calculus (ABDELKARIM; ABUIYADA; SIDDIUI, 2016; CRONHJORT; FILIPSSON; MARIA, 2013; FERREIRA; NICOLA; FIGUEIREDO, 2011; LUCAS, 2009; MILLER; SANTANA-VEGA; TERRELL, 2006; PILZER, 2001).

Akay (2011), in her study, examined the effect of the PI method on mathematics achievement and mathematics attitudes on transformation geometry for eighth-grade students. Her results indicated that PI's effect on the transformation geometry positively affected the students' mathematics achievement and their attitudes towards mathematics. Another study conducted by Abdelkarim and Abuiyada (2016) investigated PI's effect on academic achievement in mathematics of undergraduate students in Oman. The result of the study indicated that the PI strategy is an active tool to increase mathematics achievement. Further, Demirel (2013) investigated the effect of using PI in mathematics courses on students' attitude, achievement, and retention of knowledge. Survey results showed that students had significant development in their academic success in mathematic lessons; however, no significant difference in their attitudes towards mathematic lessons was observed.

Several points related to the usage of PI in math classrooms are significant. First, the late usage of PI in math topics can be attributed to the fact that there are few conceptual questions in math topics (SOMASUNDRAM; SYED ZAMRI; LEONG, 2018) when compared to science. Second, most of the publication on PI is related to calculus because calculus includes sufficient conceptual questions when compared to other math topics. Third, many of the PI studies in math are conducted in the USA and Turkey because PI was initially developed in the USA, and researchers in Turkey frequently replicate the publications done in the USA.

\subsection{The Issue}

Existing educational literature has not yet sufficiently addressed the usage of PI in teaching mathematics topics. Previous studies have several topics: systems of equations and 
inequalities (ALLISON, 2012), functions (ABDELKARIM; ABUIYADA, 2016), and statistics topics (OLPAK; BALTACI; ARICAN, 2018). Yet, the effect of PI on trigonometry has not yet been studied.

Unfortunately, research-based educational methods have not yet been widely used in post-Soviet countries, including Kazakhstan. Researchers need to focus on these countries (1) to the effect of educational methods in new populations, (2) help school development in these countries, and (3) help the improvement of science in these countries. Thus, this study seeks to search the effect of PI on ninth-grade students' trigonometry knowledge on a population from Kazakhstan. To our knowledge, this is the first study investigating the effect of PI on any subject at any level in Kazakhstan. The following research question frames this study:

- How does peer instruction affect 9th-grade students' trigonometry learning?

\section{Methodology}

This quantitative experimental research was carried out with a sample of Kazakh students from a high school on their experience with PI. An instrument comprising 25 items from the trigonometry unit was developed to gather data, which were collected at the end of the fall semester of the 2018-2019 academic year.

\subsection{Participants and Context}

The participants in this study were 89 ninth-grade students from a population of private high schools in a large city in Kazakhstan. All students were male, and the student population was approximately 90\% Kazakh, 4\% Turkish, $2 \%$ Russian, and $4 \%$ other nationalities such as Tajik, Uyghur, and Afghan.

The school is employing an educational system known as a gymnasium. While some of the courses such as physics, mathematics, biology, chemistry, and computer science are taught in English, the rest of the courses are taught in Kazakh. The pairs of classes from this school were selected for convenience due to the first author's role as a mathematics teacher in previous years. All students from this school speak Kazakh and Russian, and they also speak Turkish and English at the upper intermediate level. Students were informed of this study at the start of the autumn semester. The explanation covered the study's aim and scope, including a summary of what students could predict in terms of the curriculum that would be covered. All the participants volunteered to join this study. 


\subsection{Instrument}

In order to measure students' academic achievement in trigonometry, they developed a Mathematics Achievement Test (MAT) consisting of 39 items. The initial version of the test was prepared by considering the table of specification for the ninth-grade trigonometry unit using Bloom's revised taxonomy (KRATHWOHL, 2002). The initial version of the MAT was checked by two experts who suggested minor changes. The test was administered to 68 tenthyear students as a pilot study. The pilot application was made on tenth-year students because they had learned the trigonometry unit earlier. Item difficulty, item discrimination, point biserial correlation, and KR20 analysis were performed on the data collected from the pilot group.

Table 1 - Item Statistics for Pilot Study

\begin{tabular}{|c|c|c|c|c|c|c|c|c|c|}
\hline Item & $\mathbf{p}$ & $\bar{D}$ & pbc & KR20 & Item & $\mathbf{p}$ & $\bar{D}$ & pbc & KR20 \\
\hline 1 & 0.14 & $\begin{array}{l}-0.03 \\
\end{array}$ & -0.01 & .854 & 21 & 0.53 & 0.50 & 0.90 & .847 \\
\hline 2 & 0.94 & 0.06 & 0.19 & .850 & 22 & 0.30 & 0.26 & 0.60 & .844 \\
\hline 3 & 0.94 & 0.06 & 0.17 & .850 & 23 & 0.42 & 0.44 & 0.86 & .836 \\
\hline 4 & 0.94 & 0.06 & 0.23 & .851 & 24 & 0.50 & 0.29 & 0.54 & .845 \\
\hline 5 & 0.30 & 0.09 & 0.25 & .851 & 25 & 0.42 & 0.38 & 0.66 & .838 \\
\hline 6 & 0.78 & 0.12 & 0.23 & .851 & 26 & 0.42 & 0.38 & 0.80 & .844 \\
\hline 7 & 0.61 & 0.41 & 0.80 & .840 & 27 & 0.36 & 0.32 & 0.72 & .841 \\
\hline 8 & 0.39 & 0.18 & 0.42 & .851 & 28 & 0.75 & 0.20 & 0.53 & .839 \\
\hline 9 & 0.78 & 0.12 & 0.28 & .851 & 29 & 0.44 & 0.35 & 0.75 & .841 \\
\hline 10 & 0.69 & 0.32 & 0.70 & .844 & 30 & 0.47 & 0.32 & 0.62 & .846 \\
\hline 11 & 0.53 & 0.32 & 0.58 & .846 & 31 & 0.25 & -0.09 & -0.17 & .841 \\
\hline 12 & 0.30 & 0.26 & 0.58 & .845 & 32 & 0.33 & 0.18 & 0.39 & .843 \\
\hline 13 & 0.00 & 0.00 & 0.00 & .852 & 33 & 0.75 & 0.26 & 0.64 & .859 \\
\hline 14 & 0.47 & 0.44 & 0.83 & .840 & 34 & 0.53 & 0.38 & 0.75 & .849 \\
\hline 15 & 0.69 & 0.27 & 0.56 & .845 & 35 & 0.44 & 0.41 & 0.78 & .844 \\
\hline 16 & 0.75 & 0.20 & 0.47 & .847 & 36 & 0.22 & 0.24 & 0.64 & .841 \\
\hline
\end{tabular}




\begin{tabular}{cccccccccc}
\hline $\mathbf{1 7}$ & 0.36 & $\mathbf{0 . 0 9}$ & $\mathbf{0 . 0 6}$ & $\mathbf{. 8 5 4}$ & $\mathbf{3 7}$ & $\mathbf{0 . 0 6}$ & $\mathbf{0 . 0 6}$ & 0.39 & .842 \\
$\mathbf{1 8}$ & $\mathbf{0 . 0 6}$ & $\mathbf{0 . 0 6}$ & $\mathbf{0 . 1 9}$ & .850 & $\mathbf{3 8}$ & $\mathbf{0 . 0 6}$ & $\mathbf{0 . 0 6}$ & 0.39 & .843 \\
19 & 0.42 & 0.26 & 0.53 & $\mathbf{. 8 5 6}$ & $\mathbf{3 9}$ & 0.42 & $\mathbf{0 . 0 3}$ & $\mathbf{0 . 0 6}$ & .848 \\
20 & 0.50 & 0.29 & 0.64 & .850 & & & & & \\
\hline
\end{tabular}

*p: Item difficulty, D: Discrimination index, pbc: Point biserial correlation, KR20: KR20 if item deleted Source: Prepared by the authors

After this 39-item analysis, 14 items that had improper statistics were eliminated (See Table 1). Items that values were not between the acceptable values for two or more statistics (that is, item difficulty, item discrimination, point biserial correlation, and KR20 if item deleted) were removed. The removed items are bold and improper statistics are grey colored in Table 1. Item difficulty coefficients between 0.20 and 0.90 are considered as good and acceptable (QUAIGRAIN; ARHIN, 2017). If item discrimination $\geqslant 0.20$, then the item is functioning satisfactorily (EBEL; FRISBIE, 1972). Point biserial correlation coefficient between 0.20 - 0.39 is good, and between $0.40-0.70$ are particularly good.

As seen in Table 1, items have varying difficulty levels. Thus, we used KR20 for internal consistency reliability checks (TAN, 2009) and found a coefficient of 0.850. A teacher-made test needs to show KR20 coefficients of approximately 0.50 or 0.60 (RUDNER; SCHAFER, 2002). There is a fine agreement between other statistics and KR20. Namely, items that have improper statistics also decrease reliability. After removing the improper items, we calculated the KR20 once again and found 0.877 . Thus, the final version of the MAT, a reliable and valid test consisting of 25 items, was used for data collection in the main study.

Out of 39 items, 14 were eliminated because of improper statistics, and 25 were retained. The reason behind the elimination of many items is not the low quality of the instrument but the conduction of high-quality instruments and many statistics. That is, item discrimination, point biserial correlation, and reliability coefficient (KR20) if the item is deleted. If, for example, we had made only item difficulty and item discrimination, we would remain with many items (32). However, initially, we included many questions (39) in our test to safely remove all improper items.

\subsection{Data Collection and Data Analysis}

This study was conducted in the third period of the 2018-2019 academic year (in Kazakhstan, there are four periods in one academic year) with 89 students in Almaty. The 
implementation of PI lasted 12 weeks, and there were 33 and 34 students in the experimental and control groups, respectively. Ninth-grade students have six periods of mathematics each week, and each lesson period lasts 40 minutes.

The pre-test was administered at the beginning of the semester, and the post-test was administered after the treatment. All tests were administered during math lessons by the course teachers. Students were given 40 minutes to complete the test.

A one-way analysis of covariance (ANCOVA) test was run to examine the difference between peer instruction and regular instruction groups' post-test scores controlling their initial differences using pre-test and GPA scores at the end of the semester. ANCOVA is a popular procedure for removing extraneous error variance and for adjusting pre-existing differences among groups (HARWELL, 2003). Before conducting ANCOVA, we checked if the assumptions were met. All analysis was conducted using the SPSS 21.

\subsection{Procedures}

Initially, training was provided to the treatment group teacher on how to use PI in the classroom. Prior to the implementation of PI, two regular lessons of this teacher were observed by the first author. Except for minor mistakes (such as long student discussions after the first response), the successful application of PI was observed, and they proceeded to the treatment phase. During the treatment stage, an expert (last author) on PI strategy attended one of the lessons and found the procedure's execution successful.

The implementation of PI was carried out as described by Mazur (1997). Each lesson consisted of two parts, the first part of 10-15 minutes of the lesson was a lecture, and the PI was carried out in the remaining part of the course. For the PI, initially, two minutes were given to students to think and solve the questions by themselves. Then, students voted for their answer, and the result was reflected on the screen as a histogram. After examining the histogram, students were given two minutes to discuss their answers with peers. Students were instructed to provide reasons for their answers and to convince their peers that their answers were correct. In this format, the students had two roles: as a teacher, explaining the rationale for their answer; and as a student, listening to the reasoning of their peers' answers. At the end of the discussion, students were given a second chance to submit another response if desired ( 1 minute). The second histogram of the answers was also displayed and observed by the students. Finally, the teacher explained ( 2 minutes) the question along with student discussions, if needed. During voting, students were exhorted to submit their own responses, which they thought were correct. 
In the PI, students supply answers to each question two times, and PI is not used for all posed conceptual questions. Depending on the percentage of correct responses, three different issues are conducted: If there were less than $30 \%$ correct answers at the end of the initial answers, the teacher repeats the related topic. If the correct answers are between $30 \%$ and $70 \%$, then the peer teaching method is applied, and if the correct answers are over $70 \%$, the other question is passed (LASRY; MAZUR; WATKINS, 2008).

An example of the question asked and its initial and final histograms are as follows:

What is the maximum value of $(3 \cos x-5) / 2$ ?
A) $-1 / 2$
B) -1
C) 1
D) $3 / 2$
E) $1 / 2$

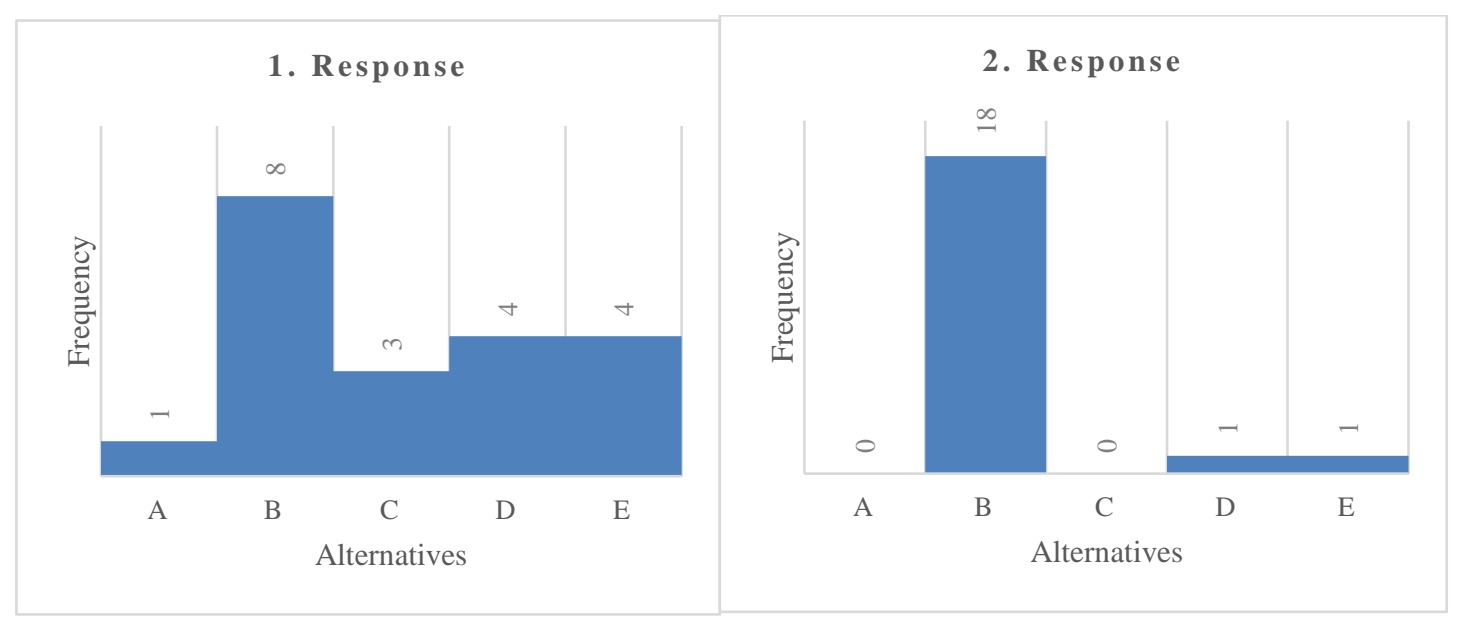

Figure 1 - A typical histogram for students' initial and second responses. The correct answer is B. Source: Prepared by the authors

As seen in Figure 1, the frequency of correct response raised from 8 to 18 while the frequency of the distractors decreased considerably.

\section{Results}

Pre- and post-test means and students' end-of-year GPA for the peer and regular groups are given in Table 2.

Table 2 - Pre-and Post-test Means and Standard Deviations

\begin{tabular}{lcccccc}
\hline & \multicolumn{5}{c}{ Peer Instruction } & \multicolumn{5}{c}{ Regular Instruction } \\
$\mathrm{N}$ & $\underline{\text { Pre }}$ & $\underline{\text { Post }}$ & $\underline{\text { GPA }}$ & $\underline{\text { Pre }}$ & $\underline{\text { Post }}$ & $\underline{\text { GPA }}$ \\
Mean & 33 & 33 & 33 & 34 & 34 & 34 \\
SD & 8.36 & 14.00 & 4.15 & 11.29 & 15.38 & 4.53 \\
& 2.06 & 2.41 & 0.57 & 5.14 & 3.14 & 0.56 \\
\hline
\end{tabular}

Source: Prepared by the authors 
Table 2 indicates that the regular group (that is, the control group) scores are higher than that of the peer instruction group (the treatment group) for all three variables. Initially, groups are not equal, so we carried out ANCOVA to eliminate pre-existing differences.

Student achievement data was initially analyzed, utilizing a percentage change. The mean of the post-test score was subtracted from the mean of the pre-test score, and the difference was divided by the pre-test score for both groups. The solution results in decimal, and by multiplying the solution by 100 , this yields the percentage change (BRULLES; SAUNDERS; COHN, 2010). The trend of the percentage change is displayed for each group in Figure 1.

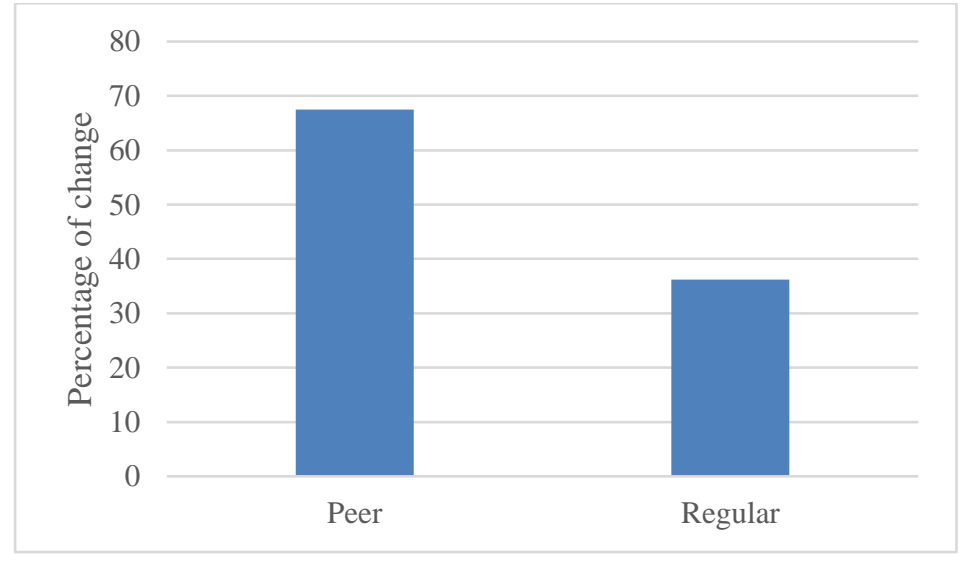

Figure 2 - Percent change by grouping; peer and regular Source: Prepared by the authors

As seen in Figure 2, the percentage change in the scores of the peer instruction group (67.46) is greater than that of the regular group (36.23). This indicates the superiority of peer instruction; however, descriptive statistics can be misleading. Therefore, we conducted inferential statistics (that is, ANCOVA) to reveal any statistically significant differences.

Prior to conducting an ANCOVA analysis, we performed a test of homogeneity for regression slopes assumption to determine the similarity of slopes. Inequality of slopes is the indication of an interaction between the covariate and the treatment (TABACHNICK; FIDELL, 2007). Analysis assessing the homogeneity of regression slopes assumption showed a significant interaction between the pre-test and the post-test while no significant interaction between the GPA and the post-test (See Figure 3). Thus, we continued with the ANCOVA analysis by only the GPA covariate. 

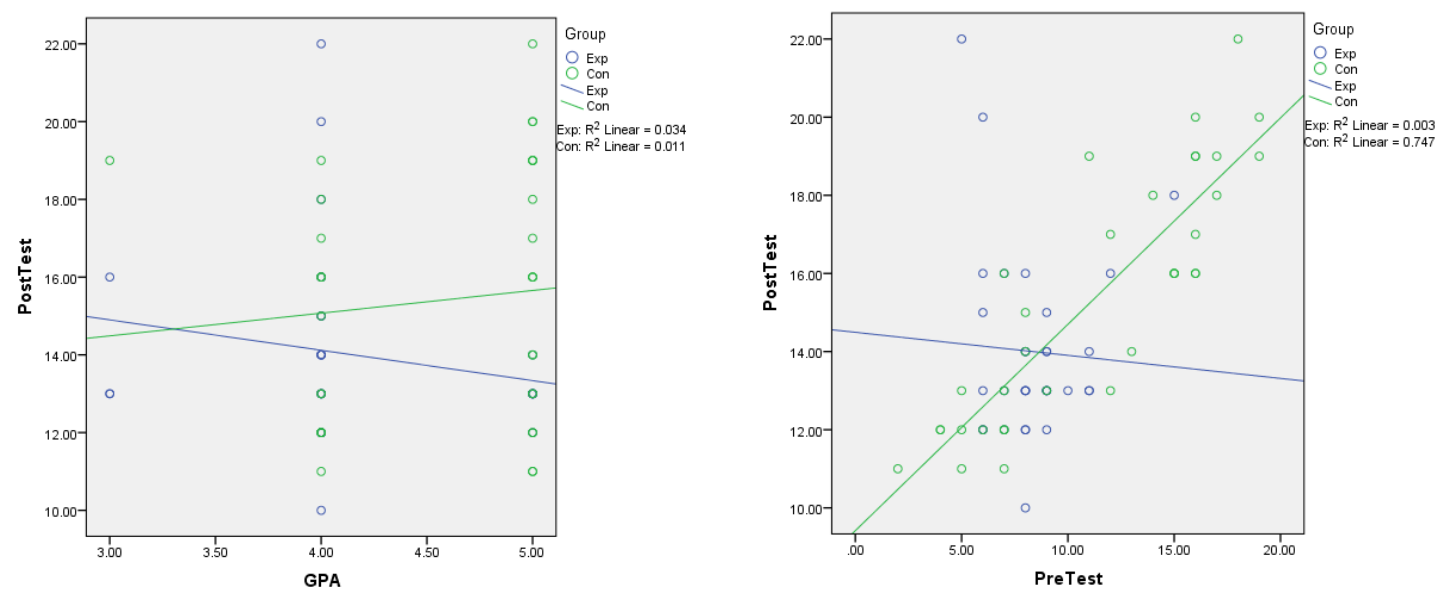

Figure 3 - Homogeneity of regression slopes Source: Prepared by the authors

ANCOVA tests were used to evaluate whether the dependent variable mean (post-test trigonometry scores), adjusted for differences in the covariate (end of year GPA), varied between the peer and regular groups. The results of ANCOVA analyses are presented in Table 3.

Table 3 - One-Way ANCOVA Conducted by Grouping

\begin{tabular}{llllll}
\hline Source & df & Mean Square & $\mathrm{F}$ & $\mathrm{p}$ & $\eta^{2}$ \\
\hline Corrected Model & 3 & 13.941 & 1.749 & .166 & .077 \\
Intercept & 1 & 242.779 & 30.456 & .000 & .326 \\
Group & 1 & 5.487 & .688 & .410 & .011 \\
Group * GPA & 2 & 4.911 & .616 & .543 & .019 \\
Error & 63 & 7.972 & & & \\
\hline
\end{tabular}

Source: Prepared by the authors

There was no significant difference in students' achievement $[F(1,63)=0.688, p=0.410]$ between the groups while adjusting for GPA. The $\eta^{2}$ value indicates the effect size. For peer instruction, the effect size is nearly zero (0.011). This value is also used to describe how much of the variance in the dependent variable is explained by the independent variables $(1.1 \%)$. Ideally, this number is fairly small.

The estimated marginal means section of the output in SPSS gives the adjusted means (controlling for the covariate GPA) for each instruction group. This simply means that the effects of GPA have been statistically removed. From these adjusted means, initial score differences are reduced, and adjusted scores are remarkably close to each other, which gave no statistical difference between the groups in the ANCOVA analysis. 
Table 4 - Adjusted Means

\begin{tabular}{lcl}
\hline Group & Mean & SD \\
& & \\
\hline Treatment & 13.850 & .520 \\
Control & 15.274 & .511 \\
\hline
\end{tabular}

Source: Prepared by the authors

\section{Discussions and Conclusions}

This study contributes to the field of existing research by adding an experimental study on the effect of a PI approach on student achievement in mathematics. This study is distinctive from other similar studies on this topic because it is the first study conducted in Kazakhstan, or perhaps the first study in the Commonwealth of Independent States.

In the study, we examined the effect of PI on ninth-grade students' performance on trigonometry at the high school level. The key outcome was that PI did not significantly affect student achievement in trigonometry. Explicitly, there was a 31\% (percentage change) improvement in the correct responses with PI when compared to regular instruction. However, when the groups pre-existence variances were considered, this difference was found to be statistically insignificant.

The outcomes of this study do not support other research which finds that PI improves student performance and learning. For instance, Crouch and Mazur (2001) found significant rises in conceptual problem-solving skills along with a 10-year duration of peer teaching experience in physics classes. Likewise, Rao and DiCarlo (2000) reported that PI improved medical student success on quizzes. Similarly, Lucas (2009) stated that PI improved student participation and comprehension. As a final example, Cortright, Collins, and DiCarlo (2005) found that a student's ability to solve novel problems was significantly improved after the PI.

The different finding from this study is that the PI did not improve student achievement on trigonometry. While PI clearly increases students' use of reasoning and discussion skills (KNIGHT; WISE; SIEKE, 2016), it does not consistently raise students' course scores (KNIGHT; BRAME, 2018). Our result about the effect of PI on students' achievement in trigonometry is similar to the above discussion. Further, it is worth mentioning that research in computer science stated less significant increases in final examination marks in a course comparing PI and regular lectures (ZINGARO, 2014).

The meta-analysis was done by Balta, Michinov, Balyimez, and Ayaz (2017), covering 
the studies published between 2000 and 2015-showed that out of the 35 studies, 34 had positive effect size values, and thus found in favor of the experimental groups using the PI technique; only one study had a negative effect size (CENTER, 2004), indicating that the control group using the traditional lecture-based method was more effective. Our result will contribute to future meta-analysis showing that PI is ineffective.

The important finding by Perez et al. (2010) can be an explanation of our result. They suggested that students choose the most common response (during second voting) because more of their classmates had firstly selected this response, and students just change their views based on the agreement of neighboring students, but not by learning through PI. In our PI implementation, in all lessons, we strongly recommended students vote independently. Thus, like Knight, Wise, and Sieke (2016) argued, we also observed the increase of students' reasoning and discussion during PI. However, it did not raise our sample's trigonometry test scores. Another possible reason for the ineffectiveness of PI in our study is the fact that we cannot assume that every student peer is also a good teacher (BÜSCHER et al., 2013).

A problem we think to be important in PI implementation is the duration of the discussion. Usually, 2-3 minutes are given to students to convince their peers. We think that this is a noticeably short duration for students who are not teachers to change their peers' minds. Thus, we agree with Lucas (2009) and think that smart students control the argument, which subsequently affects independent voting.

A limitation in the current study is that the classes in treatment and control groups were not equivalent in terms of trigonometry achievement. Starting with two equivalent classes could have yielded different results. Another limitation of our study is that we intended to equate students' pre-existing differences with two covariates (pre-test scores and students' GPA). However, assessing the homogeneity of regression slopes assumption showed a significant interaction between the pre-test and the dependent variable. Thus, we used the GPA as the only covariate, which we think is not as strong a covariate as the pre-test scores. If the homogeneity of regression slopes assumption was also met for the pre-test, it could be possible for the effect of PI to be statistically significant. Finally, all students in this study were male, and if females were added too, the results would have been different.

Future research with PI can be conducted without showing the initial histograms to control possible students' biases by class responses. We recommend the instructors to use histograms during PI judiciously. Future research is also needed to see if the PI is ineffective for other student populations in Kazakhstan. Further research could also be conducted on the influence of PI on student motivation, discussion, problem-solving skills, and retention in 
Kazakhstan. Our study implies that more robust studies are needed to reveal the real effect of PI.

\section{References}

ABDELKARIM, R. E.; ABUIYADA, R. The Effect of Peer Teaching on Mathematics Academic Achievement of the Undergraduate Students in Oman. International Education Studies, Ontario, v. 9, n. 5, p. 124-132, April 2016.

ABDELKARIM, R.; ABUIYADA, R; SIDDIUI, S. A. Undergraduate Students' Attitude towards Mathematics after Peer Teaching Experience. Global Journal of Pure and Applied Mathematics, D, v. 12, n. 2, p. 1501-1517, 2016.

AKAY, G. The effect of peer instruction method on the 8th grade students' mathematics achievement in transformation geometry and attitudes towards mathematics. (Master of Science) - Middle East Technical University (METU), Ankara, 2011.

ALLISON, T. H. The impact of classroom performance system-based instruction with peer instruction upon student achievement and motivation in eighth-grade math students. 2012. Available at: https://digitalcommons.liberty.edu/cgi/viewcontent.cgi?article=1526\&context=doctoral. Access in: January 2012

BALTA, N. et al. A meta-analysis of the effect of Peer Instruction on learning gain: Identification of informational and cultural moderators. International Journal of Educational Research, Amsterdam, v. 86, p. 66-77, 2017.

BALTA, N.; PERERA-RODRÍGUEZ, V. H.; HERVÁS-GÓMEZ, C. Using socrative as an online homework platform to increase students' exam scores. Education and Information Technologies, New York, v. 23, n. 2, p. 837-850, 2018.

BLOYD, E. S. The Effects of Peer Mediated Instruction to Teach Math Skills to Middle School Students. 2015. Thesis (Master of Science in Education) - University of Kentucky, Kentucky, 2015.

BRULLES, D.; SAUNDERS, R.; COHN, S. J. Improving performance for gifted students in a cluster grouping model. Journal for the Education of the Gifted, California, v. 34, n. 2, p. 327-350, 2010.

BÜSCHER, R. et al. Evaluation of the peer teaching program at the University children' s hospital Essen-a single center experience. GMS Zeitschrift für Medizinische Ausbildung, Cologne, v. 30, n. 2, p. 1-20, 2013.

CENTER, L. E. Issues of gender and peer collaboration in a problem-solving computer activity. 2004, v.144 [Unpublished Doctoral dissertation. Available from ProQuest Dissertations and Theses database (UMI No. 3135894)]. Rhode Island College, University of Rhode Island, Kingston, 2004.

CHAPMAN, O. Facilitating Peer Interactions in Learning Mathematics: Teachers' Practical Knowledge. In: Conference of the International Group for the Psychology of Mathematics Education, 28, 2004, Bergen. Proceedings of the 28th Conference of the International. Group ... Freudenthal, H.(1973), Mathematics as an educational task, Reidel Publishing ... v. 2, p. 191-198.

CORTRIGHT, R. N.; COLLINS, H. L.; DICARLO, S. E. Peer instruction enhanced meaningful learning: ability to solve novel problems. Advances in physiology education, California, v. 29, n. 2, p. 107-111, 2005. 
CRONHJORT, M.; FILIPSSON, L.; MARIA, W. Can Peer Instruction in calculus improve student learning? In: International Cdio Conference, 9., 2013, Massachusetts. Proceedings of the 9th International CDIO Conference, Massachusetts Institute of Technology and Harvard University School of Engineering and Applied Sciences, Cambridge, Massachusetts, 2013. p. 53-62.

CROUCH, C. H.; MAZUR, E. Peer instruction: Ten years of experience and results. American journal of physics, Oxfordshire, v. 69, n. 9, p. 970-977, 2001.

DEMIREL, F. The effect of using peer instruction in mathematic course on students' attitude, achievement and retention of knowledge. Thesis (Master of Social Sciences), Ankara, 2013.

EBEL, R. L.; FRISBIE, D. A. Essentials of educational measurement. Englewood Cliffs: PrenticeHall, 1972.

FAGEN, A. P.; CROUCH, C. H.; MAZUR, E. Peer instruction: Results from a range of classrooms. The physics teacher, Cambridge, v. 40, n. 4, p. 206-209, 2002.

FERREIRA, E. P.; NICOLA, S.; FIGUEIREDO, I. Peer Instruction method in introductory Math courses. In: INTERNATIONAL CDIO CONFERENCE, 7., 2011, Copenhagen. Proceedings..., Technical University of Denmark, 2011. p. 104-110.

GHOSH, S.; RENNA, F. Technology in Support of Good Pedagogy: Electronic Response Systems and Peer Instruction in an Economics Classroom. 2006. Available at: http://ssrn.com/abstract=888544. Access in: 10 mar. 2006

GIULIODORI, M. J.; LUJAN, H. L.; DICARLO, S. E. Peer instruction enhanced student performance on qualitative problem-solving questions. Advances in physiology education, Bethesda, v. 30, n. 4, p. 168-173, 2006.

HARWELL, M. Summarizing Monte Carlo results in methodological research: The single-factor, fixed-effects ANCOVA case. Journal of Educational and Behavioral Statistics, Kansas, v. 28, n. 1, p. 45-70, 2003.

JOHNSON, D. W.; JOHNSON, R. T. An educational psychology success story: Social interdependence theory and cooperative learning. Educational Research, Kansas, v. 38, p. 365-379, 2009.

KNIGHT, J.; BRAME, C. Peer Instruction. CBE-Life Sciences Education, Bethesda, v. 17, n. 2, p. 14. 2018.

KNIGHT, J. K.; WISE, S. B.; SIEKE, S. Group random call can positively affect student in-class clicker discussions. CBE-Life Sciences Education, Bethesda, v. 15, n. 4, p. 1-11, 2016.

KRATHWOHL, D. R. A Revision of Bloom's Taxonomy: An Overview. Theory into Practice, Bethesda, v. 41, n. 4, p. 212-218, 2002.

LASRY, N.; MAZUR, E.; WATKINS, J. Peer instruction: From Harvard to the two-year college. American Journal of Physics, Melville, v. 76, n. 11, p. 1066-1069, 2008.

LUCAS, A. Using peer instruction and i-clickers to enhance student participation in calculus.

Problems, resources, and issues in mathematics undergraduate studies, Bethesda, v. 19, n. 3, p. 219-231, 2009.

MAZUR, E. Peer Instruction: A User's Manual. Englewood Cliffs: Prentice Hall, 1997. MCDONNELL, L.; MULLALLY, M. Research and teaching: Teaching students how to check their 
work while solving problems in genetics. Journal of College Science Teaching, Arlington, v. 46, p. 68-75, 2016.

MILLER, R. L.; SANTANA-VEGA, E.; TERRELL, M. S. Can good questions and peer discussion improve calculus instruction? Problems, Resources, and Issues in Mathematics Undergraduate Studies, Bethesda, v. 16, n. 3, p. 193-203, 2006.

MORA, G. Peer instruction and lecture tutorials equally improve student learning in introductory geology classes. Journal of Geoscience Education, Bethesda, v. 58, n. 5, p. 286-296, 2010.

OLPAK, Y. Z.; BALTACI, S.; ARICAN, M. Investigating the effects of peer instruction on preservice mathematics teachers' achievements in statistics and probability. Education and Information Technologies, New York, v. 23, n. 6, p. 2323-2340, 2018.

PEREZ, K. E.; STRAUSS, E. A.; DOWNEY, N. GALBRAITH, A.; JEANNE, R.; COOPER, S. Does displaying the class results affect student discussion during peer instruction? CBE-Life Sciences Education, Bethesda, v. 9, n. 2, p. 133-140, 2010.

PILZER, S. Peer instruction in physics and mathematics. Problems, resources, and issues in mathematics undergraduate studies, Oxfordshire, v. 11, n. 2, p. 185-192, 2001.

PRAHL, K. Best practices for the think-pair-share active-learning technique. The American Biology Teacher, Maryland, v. 79, n. 1, p. 3-8, 2017.

QUAIGRAIN, K.; ARHIN, A. K. Using reliability and item analysis to evaluate a teacher-developed test in educational measurement and evaluation. Cogent Education, Oxfordshire, v. 4, n. 1, p. 1-11, 2017.

RAO, S. P.; DICARLO, S. E. Peer instruction improves performance on quizzes. Advances in physiology education, Rockville, v. 24, n. 1, p. 51-55, 2000.

RUDNER, L. M.; SCHAFER, W. D. What teachers need to know about assessment. Washington: National Education Association, 2002. Available at:http://echo.edres.org:8080/nea/teachers.pdf. Access in: 01 jul. 2002

SOMASUNDRAM, P.; SYED ZAMRI, S. N. A; LEONG, K. E. Year Five Pupils' Understanding of Relationship Between Addition and Subtraction. Journal of Research in Science, Mathematics and Technology Education, Harrisonburg, v. 1, n. 2, p. 169-180, 2018.

TABACHNICK, B. G.; FIDELL, L. S. Using multivariate statistics. 5. ed. Boston: Allyn and Bacon, 2007.

TAN, S. Misuses of KR-20 and Cronbach's alpha reliability coefficients. Education and Science, Bursa, v. 34, n. 152, p. 101-112, 2009.

VASAY, E. T. The effects of peer teaching in the performance of students in mathematics. EInternational Scientific Research Journal, Gujarat, v. 2, n. 2, p. 161-171, 2010.

VICKREY, T.; ROSPLOCH, K.; RAHMANIAN, R.; PILARZ, M.; STAINS, M. based implementation of peer instruction: A literature review. CBE-Life Sciences Education, Ohio, v. 14, n. 1, p. 1-11, 2015.

YAVUZ, O. C. Effect of peer instruction enriched by the web-based peer and selfself-assessment system on the achievement and attitude of the 7th grade students in rational numbers. Dumlupinar University [Unpublished Doctoral dissertation], Kütahya, Turkey, 2014. 
ZINGARO, D. Peer instruction contributes to self-efficacy in CS1. In: ACM TECHNICAL SYMPOSIUM ON COMPUTER SCIENCE EDUCATION, 45, 2014, New York. Proceedings... New York: ACM Press, 2014. p. 373-378.

Submetido em 20 de Jullho de 2020. Aprovado em 21 de Novembro de 2020. 